\title{
The Challenge of Uninvited Guests: Social Art at The Blue House
}

\author{
Zara Stanhope
}

The Blue House was an ambitious and multifaceted social art project conceived and conducted by Dutch artist Jeanne van Heeswijk from mid- 2005. ${ }^{1}$ The project involved artists and others undertaking social art research practices to investigate the then newly established, highly planned neighbourhood of IJburg in Amsterdam, the capital of the Netherlands. In this paper I examine how The Blue House illustrates the potential of sociality in art by encouraging engagement with others, and thereby ultimately fostering world-making relations through diverse intersections of art and daily life. I will argue that as art, The Blue House makes evident the relational nature of the world that scholar Sen-Ami Scharpstein locates both within the individual and across the globe at large. ${ }^{2}$ In this sense, I examine how The Blue House encouraged individual capacity for agency or making worlds in the relations and creative projects established between individuals, but also how, beyond the local, members of The Blue House also engaged social issues of global significance, such as the effects of global capitalism and significance of notions of citizenship and personal sovereignty in a progressively interconnected world. In generating temporary interventions into everyday life, I highlight how The Blue House evidences artists exploring their personal capacity for world-making, and social art practice 'becoming art of the world'; following art historian Terry Smith's definition of contemporary art. ${ }^{3}$ In becoming art of the world, I also show how the resident artists were unintentionally implicated in areas of state social policy, and creative industry imperatives. As such, this essay provides a rare opportunity to observe the local and global intersections between art, state and industry through a social art lens that is The Blue House.

\section{Social Art}

Nicholas Bourriaud's proposition of relational aesthetics in his book Esthétique relationnelle was a catalyst for renewed interest in the theory and practice of

1 Het Blauwe Huis operated from June 2005 to December 2009.

2 Scharfstein, S-A. 2008, 'Pre-lude: Keeping the World Together', in K. Zijlmans and W. van Damme (eds), World Art Studies: Exploring Concepts and Approaches, Amsterdam, Valiz, p. 11.

3 Smith, T. 2011, Contemporary Art: World Currents, London, Laurence King Publishing. 
social art at the turn of the twenty-first century. ${ }^{4}$ Bourriaud located art taking the form of social relations as both the means and ends of art. He contended the sociality of audiences, interacting to form micro-communities, offered an alternative political model for the hyper-connected globalised world where economic and legal systems and the mass media have primacy over social and civic connections. Bourriaud's ideas contributed to new developments in art theory, particularly the development of critical aesthetics that analyses audience involvement in 'social art' in terms of models of communality or avant-garde tactics.

'Relational art', and similar forms of 'participatory art' and 'social art', have become prominent in art since the 1990s. Social art appears in gallery and public spaces, and is often commissioned within larger art events. Definitions of various sub-forms of social art have arisen in response to Bourriaud's relational aesthetics. In this essay I identify the key developments in social art that provide a framework for understanding The Blue House.

In the United States, from the late 1980s, artist Suzanne Lacy's 'new genre public art' explored social issues of marginalisation and discrimination in local communities. Lacy associated her practice with the performative art of her mentor Allan Kaprow, and also with the new forms of public/site specific art curated by Mary Jane Jacob. ${ }^{5}$ In contrast to the amelioration of social issues in art, in Europe the emphasis on the politics of participation has been identified in the curation of the exhibition Kontextkunst, Kunst der 90er Jahre by Peter Weibel. ${ }^{6}$ The burgeoning practices of social art continue to stimulate critical responses from art historians and theorists, in which the key figures, predominantly Claire Bishop, Grant Kester and Claire Doherty, have interpreted social art through theories of alternative politics and personal ethics. ${ }^{7}$

The political context of The Blue House project as social art originates with Jeanne van Heeswijk's twenty year involvement with social art in urban communities. ${ }^{8}$ The Blue House project was new in engaging with the unique social and urban

4 Bourriaud, N. 2002, Relational Aesthetics [Esthétique relationnelle], trans. S. Pleasance and F. Woods, Dijon, Les presses du réel. The Happenings organised by American artist Allan Kaprow, and many of the ideas of the Situationist International formed in Europe in the late 1950s, or the social sculpture of Joseph Beuys initiated in the 1970s, are understood as precedents for social art of the 1990s.

5 Formative texts include Lacy, S. 1995, Mapping the Terrain, New Genre Public Art, Seattle, Washington Bay Press, and Jacob, M. and Brenson, M. 1998, Conversations at the Castle, Changing Audiences and Contemporary Art, Cambridge, Massachusetts: The MIT Press.

6 Kontextkunst-Kunst der 90er Jahre [Context Art -Art of the 90s] was exhibited at the Neue Galerie im Künsterlerhaus Graz, Austria in 1993.

7 See Bishop, C. (ed.), 2006, Participation, Documents of Contemporary Art series, London and Cambridge, Massachusetts, Whitechapel and MIT Press; Kester, G. 2004, Conversation Pieces, Community and Communication in Modern Art, London, University of California Press; and, Doherty, C. (ed.), 2004, Contemporary Art, from Studio to Situation, London, Black Dog Publishing.

8 See Billing, J., Lind, M. and Nilsson, L.(eds), 2007, Taking the Matter into Common Hands, London, Black Dog Publishing; and, Jeanne van Heeswijk, http://www.jeanneworks.net/ 
circumstances of IJburg as a man-made extension of Amsterdam into the bordering lake, as well as with the global connectivity of the Netherlands as a function of its nation status. The project achieved notable outcomes within the realm of social art and its emancipatory politics. However, while ambitiously aiming for autonomy from state accountability, The Blue House revealed an unintended intersection between social creative practice, and state and commercial concerns. In the following, I will demonstrate how The Blue House evidences the potential of individual relations as creative responses to context. This, I argue, stands in contrast to the autonomous democratic communicative action or avant-garde oppositionality proposed for social art by art historians such as Bourriaud and Bishop. ${ }^{9}$

\section{The Effect of World Connectivity on the Netherlands}

The Blue House was situated on Harbour Island (Haveneiland), the largest of the eight artificial islands that comprise the IJburg district in Amsterdam. City planners conceived the concept of the islands in 1996 as part of the policy to create 70,000 new homes by 2030. ${ }^{10}$ The population growth in the Netherlands is partly a legacy of the colonisation undertaken for trade from the seventeenth century, subsequent immigration policies, and the continued desire to attract corporate business as the nation engages as a neoliberal economy in global capitalism. Alongside the high priority given to local social welfare remaining from the national emphasis on social policy post-war, the Netherlands subscribes to global capitalism as a modern industrialised nation. The country fulfils the definition of economic globalism in being open to the world market and the internationalisation of private property, facilitating the mobility of resources, investments, labour, profits, and adhering to the primacy of the law and judicial system, while prioritising civic and political rights. ${ }^{11}$ Ultimately IJburg was part of intentions to reinvigorate Amsterdam's edge in pursuit of competitiveness

9 Bourriaud, Relational Aesthetics, and Bishop, C. 2004, 'Antagonism and Relational Aesthetics', October, vol. 110, pp. 51-79.

10 de Rooy, F., Val, W. and Vierboom, G. 2002, IJburg in uitvoering 8:2, Amsterdam, De Zuiderkerk, pp. 23-4; and, de Lange, L. and Milanovic, M. 2009, De afronding van IJburg, PlanAmsterdam 2, 15:2 Amsterdam, Dienst Ruimtelijke Ordening, pp. 27-8. The Netherlands returned to a policy of increasing inner city density in the late 1990s, after previously encouraging the working population to move out of Amsterdam to new suburbs and towns such as Almere.

11 Global capitalism or economic globalisation defined in Boaventure de Sousa Santos, 2006, 'Globalizations' Theory Culture Society, vol. 23, pp. 393-4. The strong state concern for social rights in the Netherlands post World War II meant it did not adhere to the weak state 'Washington consensus' model of globalisation with low priority given to social welfare policies. The Netherlands organised itself as welfare state society post World War II replacing the pillarised society of co-existing ideologies that previously provided many social and cultural services. 
as a global city in financial and business services. ${ }^{12}$ Plans for the city's global positioning include developing a 'five star' business district along the city's south access, and constructing a Manhattan style metropolis on the banks of the IJmeer to easily facilitate business, investors, employees and tourism activities including IJburg. ${ }^{13}$

With the influx of immigrants over the last 30 years the population density has swelled dramatically, generating significant constraints in the Netherlands. ${ }^{14}$ Formative for IJburg and The Blue House was the arrival of one million immigrants primarily from the former South-American Dutch colony of Suriname, Indonesia, as well as Turkish and Moroccan workers being upgraded to permanent settlement. ${ }^{15}$ The establishment of IJburg therefore reflects both global corporatism and the instrumental role of the government in social services and urban planning. ${ }^{16}$ IJburg was part of an estimated 750,000 new affordable, suburban housing units proposed in 1993 to accommodate population growth over the ensuing two decades. ${ }^{17}$

As a flagship development, IJburg affords the city's global competitive position by providing (upper middle class) owner-occupied housing and the same time enables the Netherlands government to implement social and cultural blending through social housing as a policy priority. The initial two islands were planned to comprise 18,000 homes for 45,000 residents, numerous cultural and service facilities, and an anticipated provision of 12,000 jobs by $2013 .{ }^{18}$ However, at the time The Blue House was initiated, the Amsterdam Projectburo - the city planning authority and administrative body of IJburg - had slowed the pace of development as a result of ING Real Estate having withdrawn from the

12 In contrast to the Netherlands' seventeenth century 'Golden Age' that was based on the international trade undertaken by the Dutch East and West India Companies with the territories encountered during exploratory sea voyages.

13 Oudenampsen, M. 2007, 'Amsterdam TM, the City as a Business', in BAVO (ed.), Urban Politics Now, ReImagining in Democracy in the Neoliberal City, Rotterdam, NAi Publishers, pp. 111-5.

14 In 2006 the 'foreign population' comprised 19 per cent of the total Netherlands population (16.3 million), with just more than half from non-Western backgrounds. Ministry of Education, Culture and Science, 2006, Cultural Policy in the Netherlands, The Hague, p. 21. The impact of immigration included unemployment rates between 7-6 per cent of employable population during 2004-2006.

15 A large number of Dutch national Surinamese immigrated after Suriname gained independence in 1975. Turkish and Moroccan immigrants were recruited to work in the country from the mid-1970s. Dutch population statistics (2008 est.) were: Dutch 80.7 per cent, EU 5 per cent, Indonesian 2.4 per cent, Surinamese 2 per cent, Moroccan 2 per cent, Caribbean 0.8 per cent, other 4.8 per cent, according to Central Intelligence Agency, The World Factbook, viewed 8 November 2011, https://www.cia.gov/library/publications/the-worldfactbook/geos/nl.html

16 This is despite restraint in welfare state governance from the 1980s to counter national cost expansion in the 1970s. Apart from social intervention, Dutch urban policy is a mechanism used to accommodate workers near industrial zones, and in flood prevention (as nearly half the country is below sea and river level).

17 The VINEX (Vierde Nota Ruimtelijke Ordening Extra) guidelines for redevelopment of existing centres was established by the Dutch Ministry of Housing, Spatial Planning and the Environment, in 1993.

18 de Rooy, F. et al 2002, IJburg in uitvoering, De Zuiderkerk, Amsterdam, vol. 8, no. 2, pp. 23-4. 
Private Public Partnership. Other private companies took over construction and consequently the Projectburo's influence on building was diluted and aspects of development were delayed. ${ }^{19}$

IJburg is a unique reclamation project. Every square metre of public and private space was predesigned by the city Projectburo with an absolute level of bureaucratic control described by David Harvey as 'neoliberalised urban authoritarianism'.$^{20}$ The Projectburo plans included a beach, harbour, marina, park, nature reserves, shops and a community centre, to be established when the population reached target numbers. However, many of these facilities and more than half of the expected 12,000 jobs on IJburg were delayed until the second phase of island construction, also deferred from 2010, and yet to begin when the research was undertaken. ${ }^{21}$

\section{The Blue House (Het Blauwe Huis)}

Dutch artist Jeanne van Heeswijk, with two other collaborators, established a base for researching, questioning and intervening in the pre-planned urbanism of IJburg during its construction. ${ }^{22}$ IJburg came to van Heeswijk's attention when she was invited by the city to undertake another project in the area. ${ }^{23}$ She declined this invitation but in 2005, van Heeswijk negotiated to have a villa, an exceptionally large home with a distinctive blue exterior, removed from the housing market until 2009. ${ }^{24}$ This villa became known as The Blue House.

The Blue House is situated at the centre of Block 35 on Haveneiland. The house is surrounded by private homes, social accommodation, rental units designed for all ages and stages of life, as well as housing for a religious community. The Projectburo planned to attract over 102 nationalities to IJburg on completion. ${ }^{25}$ Hence, Block 35 included 'poor people, rich people, families, singles and couples, white people, black people all together' within a 50 metre span according to resident Marius Knulst, in 'houses worth 700,000 euros ... [that] people rent

\footnotetext{
19 Igor Roovers interview with the author, 21 May 2010.

20 Harvey, D. 2000, Spaces of Hope, Edinburgh, Edinburgh University Press.

21 Roovers interview with the author, 21 May 2010.

22 Dennis Kaspori (architect) and Herve Paraponaris (artist) were close collaborators with van Heeswijk on the direction of The Blue House. The house was designed by Teun Koolhaas Associates.

23 Van Heeswijk was invited to apply for a grant from the Amsterdam Fonds voor de Kunsten (Amsterdam Funds for the Arts) to propose public artwork for Block 35 or IJburg. O'Neill, P., and O'Doherty, C. (eds) 2011, Locating the Producers, Durational Approaches to Public Art, Amsterdam, Valiz, , p. 22.

24 Unsold during development, de Alliante Housing Corporation agreed the house be used for five years for cultural activities in exchange for payment of the mortgage rent. The Blue House was established as a foundation, with van Heeswijk as an adviser.

25 de Lange, L. and Milanovic, M., 2009 PlanAmsterdam, De afronding van IJburg 2, p. 27.
} 
for 400 euros a month' ${ }^{26}$ On establishment, The Blue House was the only social space on the island, apart from a 'shop' unassociated with the project, operating out of a tent for a few hours a day. ${ }^{27}$

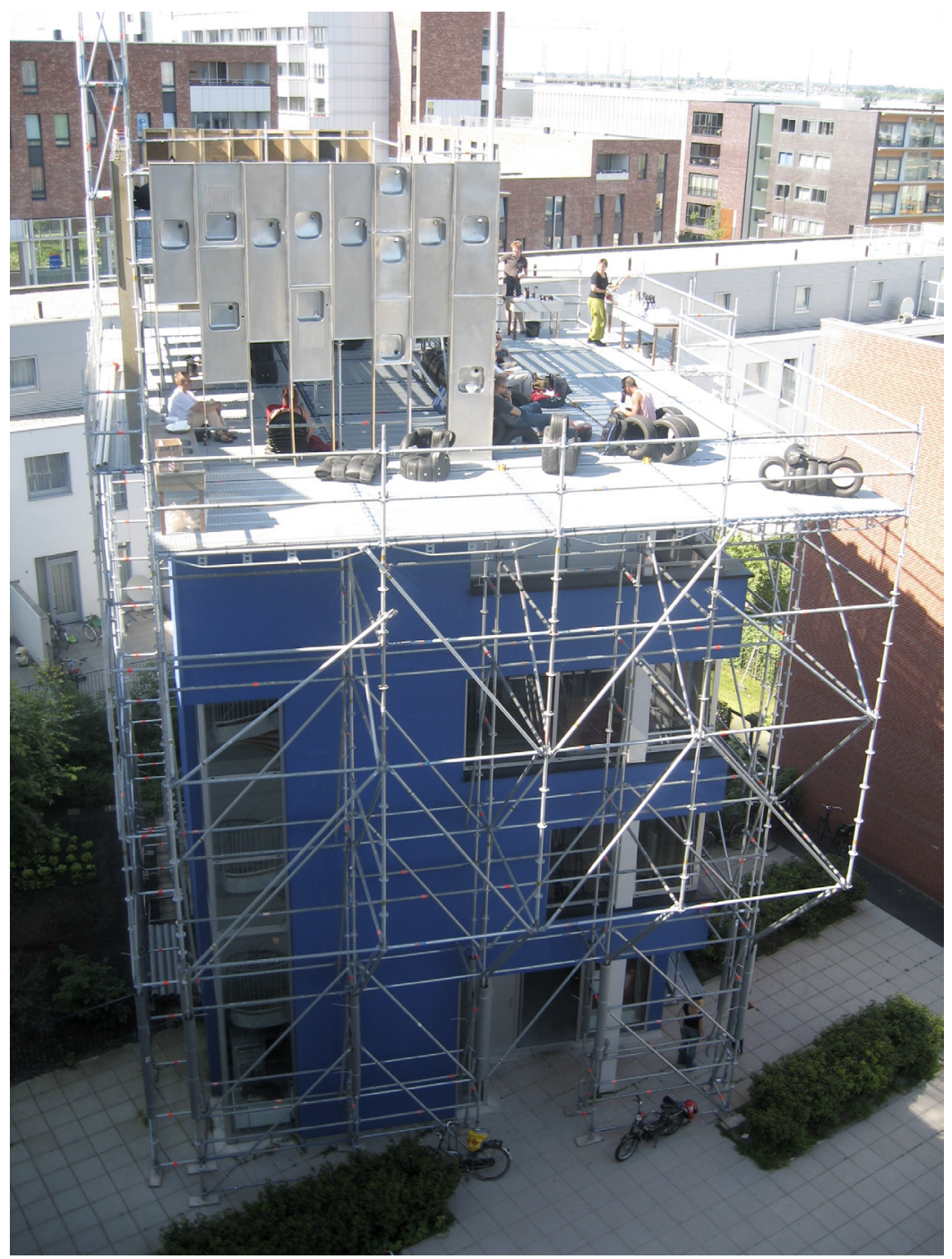

\section{Pump up The Blue, 2007, Herve Paraponaris, with Recycloop architects at The Blue House (Het Blauwe Huis).}

Photograph by Ramon Mosterd. Image courtesy Jeanne van Heeswijk

26 Paul O'Neill interview with Marius Knulst 'Locating the Producers, Case Study One - The Blue House', 11 April 2008, p. 2, unpublished.

27 Member Daniela Paes Leão noted that there was no community structure, no places to meet, and that people didn't know each other or have a social conscience, in Daniela Paes Leão, 'Letter', The Blue House, viewed 23 June 2010, http://www.blauwehuis.org/blauwehuisv2/?news_id=1917 
In The Blue House van Heeswijk offered a base for responsive investigations into IJburg that questioned the effect of the specific nature of IJburg's built environment on the lives of residents. Van Heeswijk encouraged these 'fields of interaction' offering financial support to facilitate short and long term engagements with the project and its residents. The organisation of The Blue House comprised one aspect of the research project for van Heeswijk. ${ }^{28}$ In addition, van Heeswijk recruited 'members' to form the 'Blue House Housing Association for the Mind' as the self-organised network and structure for key decision-making in the project. ${ }^{29}$

In terms of the membership of the project, some had previously collaborated with van Heeswijk, while others were invited on the grounds of art practices or interests in urbanism or social infrastructure. ${ }^{30}$ The fluctuating membership comprised local and international artists, art theorists, curators, a philosopher, a writer, artist and architect collectives, students, a sociologist, a number of IJburg inhabitants and the European Cultural Foundation. ${ }^{31}$ For members outside Amsterdam, the main benefit was the right to stay in the House for up to a total of six months on the condition of sharing 'research' with the other members. ${ }^{32}$ IJburg residents whose proposals were found relevant to the research purpose also became members of The Blue House. ${ }^{33}$

For van Heeswijk, financial autonomy was a significant factor in the independence of the project. Van Heeswijk refused financial support offered by the City of Amsterdam and the IJburg Projectburo, finding financial and in-kind support from sources not associated with the normative intervention or accountability she associated with cultural funding. ${ }^{34}$ Members could also bring additional funds for their project or utilise the house as a partner in fundraising.

\footnotetext{
28 For example, van Heeswijk swapped roles with member, Igor Dobricic, the arts program officer at the European Cultural Foundation, a funder of The Blue House, to understand how exchange between artists and foundations could be more than symbolic. She also established the legal and operational structure for The Blue House project.

29 Members mostly lived beyond Amsterdam, predominantly in the Netherlands and Europe.

30 Members suggested other colleagues, however, van Heeswijk had final say in the membership according to Marianne Maasland interviewed by Paul O'Neill 'Locating the Producers, Case Study One - The Blue House', 12 April 2008, p. 5, unpublished.

31 There were 51 members, which included 22 artists or art collectives. In addition, 36 students from MaHKU, Utrecht were involved in projects as part of their studies with Henk Slager, Jeanne van Heeswijk and Dennis Kaspori. O'Neill and O'Doherty (eds), Locating the Producers, p. 10.

32 Most members divided the six months into shorter periods, according to house manager Irene den Hartoog, in Paul O'Neill interviews with Irene den Hartoog and Daniela Paes Leão Paul, 'Locating the Producers, Case Study One-The Blue House', 12 March 2008, p. 3, unpublished.

33 Project proposals had to demonstrate specific relevance to van Heeswijk's brief. One artist was removed for ideas that did not comply with the purpose and open form of the membership, in Jeanne van Heeswijk interview with the author, 17 June 2011.

34 In association with the foundation, van Heeswijk raised funding for artists' fees, the house mortgage interest and other costs. Members were supplied with 6,000 euros (1,200 per month of residency) and travel costs. Funds and in-kind support were sourced from the European Council Foundation (ECF), Amsterdam Funds for the Arts (AFK), de Alliante (Private Housing Corporation), the Mondriaan Foundation and the Prince Bernhard Culture Fund. Also Stitchting DOENand VSB Fonds according to O'Neill and O'Doherty, Locating the Producers, p. 30 .
} 
Understanding how Projectburo planning had overlooked needs for productive social life in the first phase of IJburg formed principal motivation for The Blue House - and in particular, the project's research into the 'unplanned', as van Heeswijk described it. The research or social art of members also resisted and was to influence urban policy, as described by member Igor Dobricic who discussed how The Blue House aimed to 'make a hole' in the density of the social engineering through which other things might emerge. ${ }^{35}$ Members had complete latitude to research the unplanned situations independent of critical or curatorial guidance, and employed idiosyncratic heuristic methodologies to engage with neighbours. Van Heeswijk and her collaborators considered members' projects addressed three broad themes: questions of how history, instant urbanism (or immediate responses to necessities for daily life), and hospitality might be created.

\section{Connectivity in New Urban Planning}

The various forms of research arose from members' responses to personal connections and individual communications with IJburg neighbours and residents. In its first years the house was open to visitors two days a week. Despite living in full view of neighbours at the centre of Block 35, members admitted to being challenged as to how to interact with IJburg residents, busy with their daily lives. ${ }^{36}$ Invitations were extended to the neighborhood residents from The Blue House - face-to-face, by flyers and digital media, and through the press - to attend meetings and events, to use rooms within the house as flexible spaces, or to come and socialise over coffee. The house was also a repository for information on IJburg. That The Blue House was an art and not a community project raised a great deal of interest across Amsterdam, and confounded residents with unconventional ideas of art. ${ }^{37}$

Some of the outcomes generated through projects conducted by members, in consultation with Block 35 residents, included: gathering information and leading public discussions from the house and in the media; running workshops for locals, teaching, coordinating and producing projects ranging from films, a provisional motel, and outdoor cinema, to a restaurant and libraries; and providing boat and bike transport. Social processes were both fieldwork research and individual responses to IJburg life. In the following section I give a short

35 Igor Dobricic in Paul O'Neill interviews 'Locating the Producers, Case Study One - The Blue House', 12 March 2008, p. 5, unpublished.

36 Daniela Paes Leão interview with the author, 22 May 2010.

37 Van Heeswijk and the live-in house manager who replaced her after six months, Irene den Hartoog, were proactive in engaging with neighbours. The Blue House also attracted hundreds of curious visitors on weekends, according to van Heeswijk, in Jeanne van Heeswijk interview with the author, 17 June 2011. 
overview of a selection of projects that indicate the multiple and contingent forms in which the potential for personal agency and connectivity through intersubjective world-making was generated by members and residents.

A number of members approached the research question sociologically, documenting subjective histories of a new place. Ella Gibbs and Amy Plant interviewed Projectburo planners and workers building the island. Their film, IJbuild, offered a sense of the global origins and vast amount and range of material and personnel involved in the construction. Art historian Marianne Maasland and sociologist Marga Wijman conducted periodic surveys of residents' responses to the ongoing transformation of local public spaces. Mauricio Corbalán and Pio Torroja of architecture collective m7red organised a series of conversations on the notion of public space, entitled 'Chat Theatre', which addressed subjects ranging from citizenship and immigration to the role of new media in public space. Participants in Porto Alegre joined the dialogues by means of software developed by the collective. ${ }^{38}$

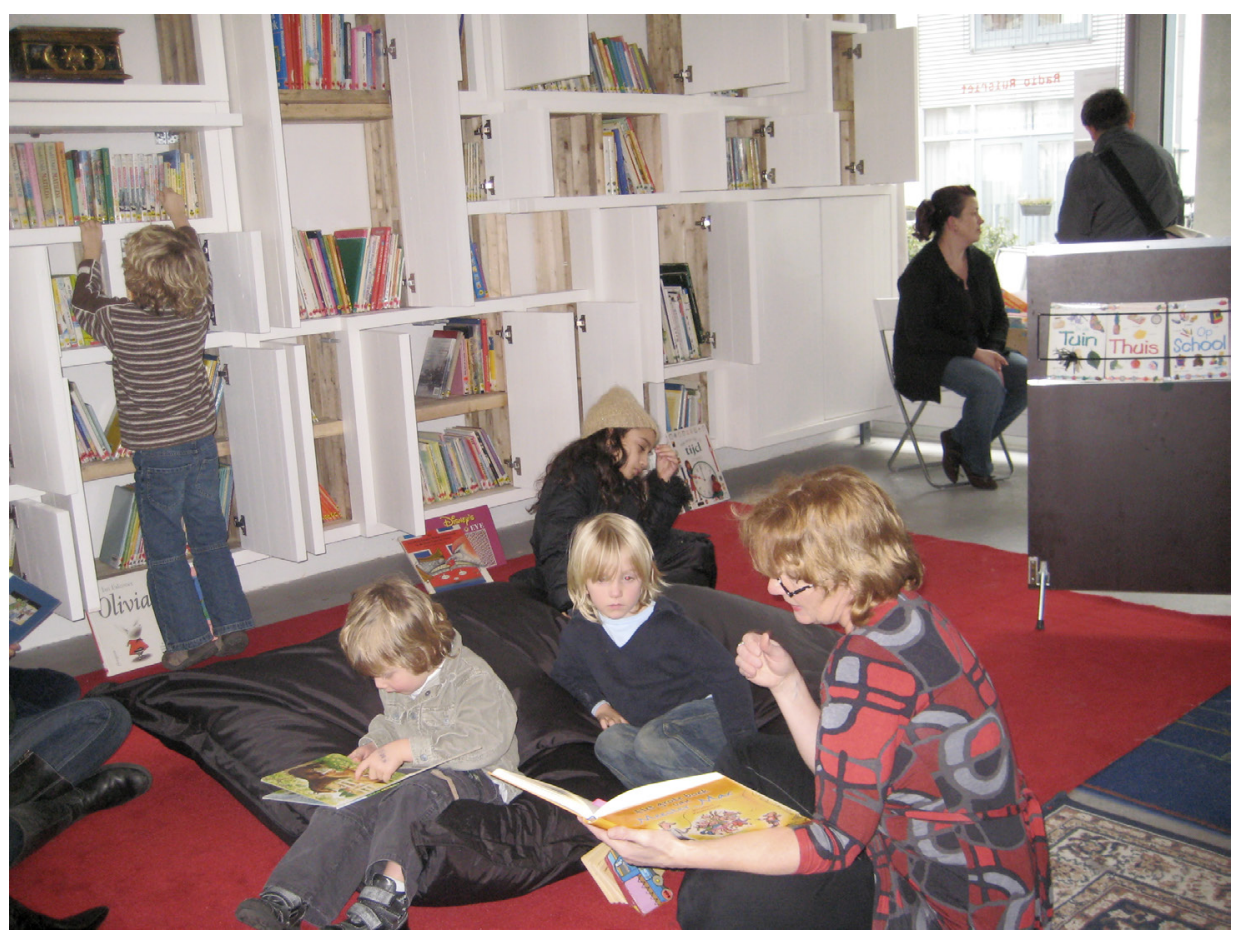

Children's Library (Leesjeblauw), 2009, Marthe van Eerdt with Jeanne van Heeswijk and Dennis Kaspori at The Blue House (Het Blauwe Huis).

Image courtesy Jeanne van Heeswijk

38 See http://www.blauwehuis.org/blauwehuis2/?project_id=17 viewed 23 August 2011. 


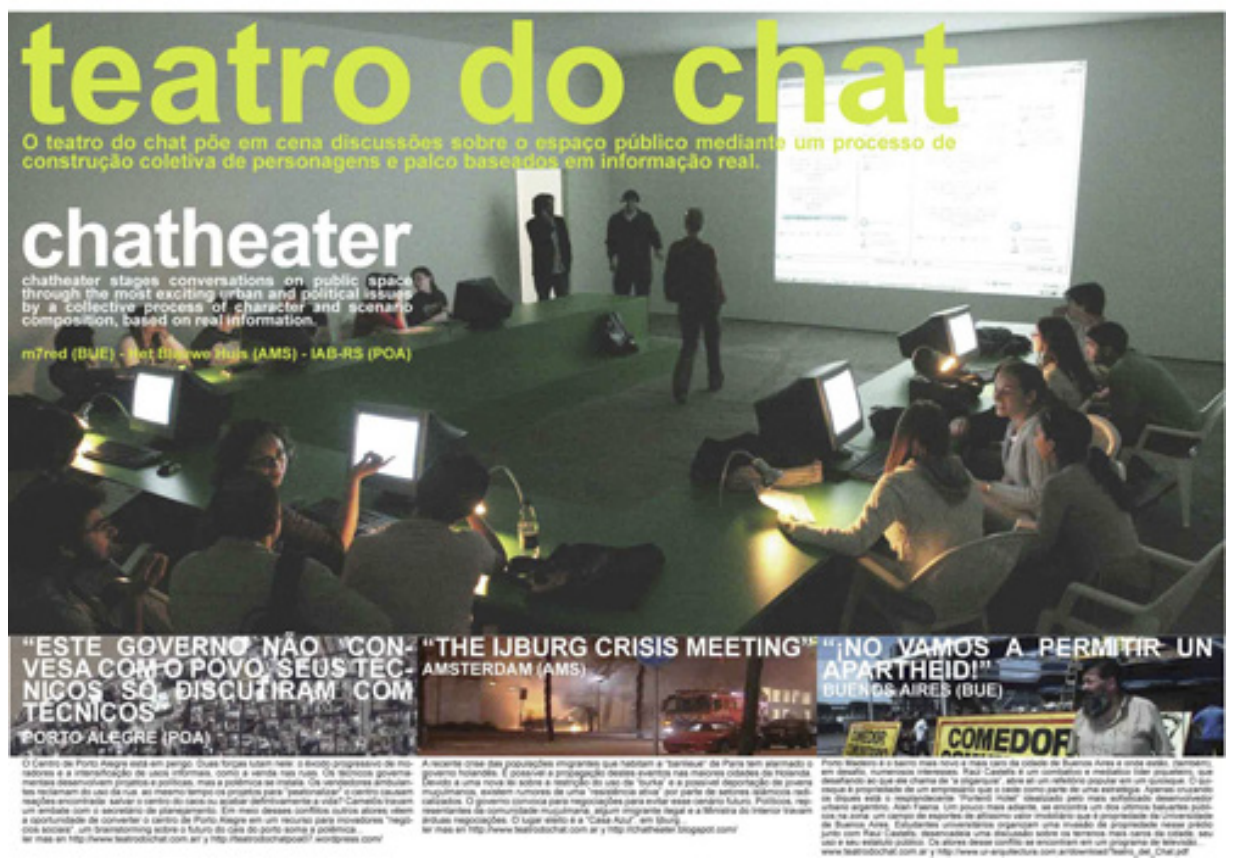

Chat Theater, 2006, m7red with Jeanne van Heeswijk at The Blue House (Het Blauwe Huis).

Image courtesy Jeanne van Heeswijk

As urban researchers, Transparadiso (artist Barbara Holub and architect Paul Rajakovics) with Timon Woongroep conducted interviews with residents and reacted to the sense of betrayal that development had blocked and enclosed the once expansive lakeside atmosphere of the IJmeer. With residents from Block 35, they built a 12-metre high periscope on a roof terrace for public use which they entitled, View-On! (2009), and designed a new housing block model entitled, Blue Fiction-The Blue Block (An Anachronistic Centre), based on members' visions and existing plans. ${ }^{39}$ As a consequence, residents petitioned the Projectburo regarding future building. Other responses arising from listening to residents' ideas of the 'unplanned' included an environmentally-friendly motel entitled Autohotel (2007) organised by Evelien de Munck Mortier. The motel took the form of customers' parked cars that were fitted out for sleeping, and the use of bathrooms and lounges in the homes of residents.

Rudy J. Luijter's edible Public Garden (Publieke moestuin) (2006-9) was a communal project for the residents of Block 35, and a response by the artist to the unplanned fencing of public space by residents. To add functional space

39 The periscope on Maria Austriastraat comprised a collaboration with Anjo and Aline Terpstra of Timon Woongroep, and was open to the public on weekends. 
to the The Blue House itself, Herve Paraponaris instigated Pump Up the Blue in 2007, a scaffold structure built around and above the house. The room built across the roof provided an interim space for a youth program run in cooperation with local teenagers, the Chill-ROOM, until the planned youth centre became available. ${ }^{40}$ This initiative led to Block 35 residents overcoming their antipathy towards teenagers, who had been given bad press on the island, and finally supporting the weekly operation of the Chill-ROOM over the 2008-09 period. Subsequently, a care facility was set up providing formal activities for teenagers, and the official community centre development was brought forward to 2009 from the scheduled 2012 opening. ${ }^{41}$

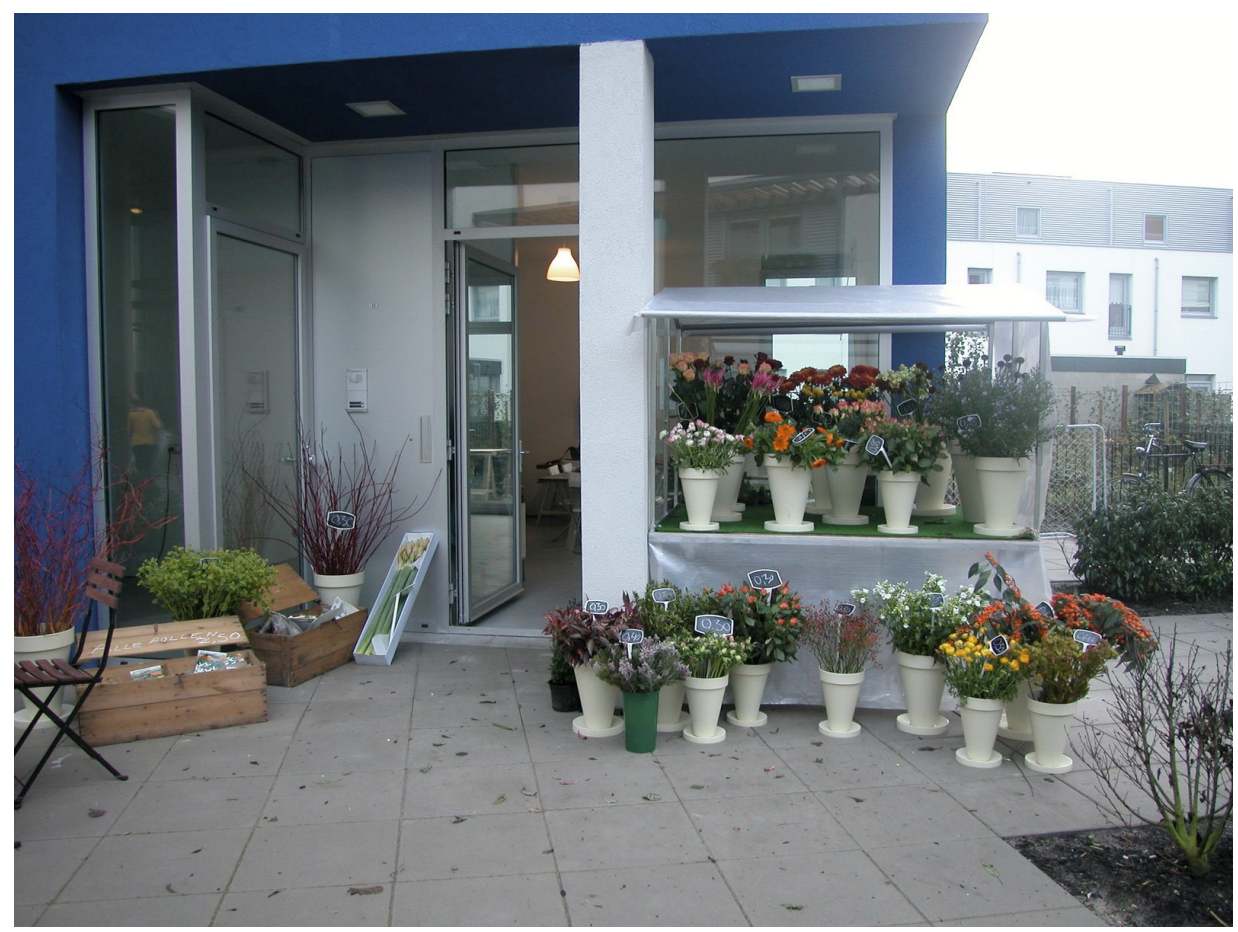

\section{Flowers for IJburg (Bloemen voor IJburg), 2005, Nicoline Koek with Jeanne van Heeswijk and Dennis Kaspori at The Blue House (Het Blauwe Huis).}

Image courtesy Jeanne van Heeswijk

40 The Chill-ROOM was instigated by Ingrid Meus, a student in a public art course run by van Heeswijk, one of a number of classes held at The Blue House. The program was operated by a social worker. Van Heeswijk interview with the author, 17 June 2011.

41 The presence of youth on the island and at The Blue House in Block 35 raised heated local debate with residents, noted by Denis Kaspori in Paul O'Neill interviews 'Locating the Producers, Case Study One - The Blue House', 12 March 2008, p. 5, unpublished. Block 35 residents nearly did not approve of Pump Up the Blue and the Chill-ROOM but gave their permission and some residents even contributed equipment once the program was operating, according to van Heeswijk in Jeanne van Heeswijk interview with the author, 17 June 2011. 
Van Heeswijk and Dennis Kaspori activated and facilitated a number of projects engaging with opportunities or activities perceived as absent from IJburg. They assisted Nicoline Koek to overcome inflexible trading laws and establish her flower stand, Flowers for IJburg (Bloemen voor IJburg), in the eight square metres of private land in the front of The Blue House. Operating each Saturday from 2005 to 2007, the flower stand became an icon in the district and was much appreciated by residents for brightening up their environment both visually and as a point of social contact. ${ }^{42}$

Local resident Maarthe van Eerdt was allocated the largest room in the house to provide a weekly children's library (the official children's library was planned for the 2008 forecasted population). Another resident initiated a book exchange for adults (in advance of the official service planned for 50 years hence). The Blue House members later assisted these activities to relocate to other local spaces. ${ }^{43}$ In 2006, van Heeswijk's and Kaspori's urbanism project also addressed the lack of a social or community 'restaurant' on the island, by offering an affordable catered meal once a week at the Community Restaurant or Proeflokaal (2006). ${ }^{44}$

The projects conducted at The Blue House highlighted gaps in institutional planning, demonstrated local social attitudes, and created debate about the role of art in society. Many projects at The Blue House were relevant to global and local political and social environments in researching the nature of hospitality, understood as the relations between the guests and host that include the ethics of respect for strangers. A small number of new residents vocalized their outrage at finding their new neighbourhood contained members of immigrant populations and an emergence of associated social issues they had expected to escape by moving to IJburg. For despite the former reputation of Holland as a relatively tolerant, pluralistic society, ${ }^{45}$ at the time of The Blue House project, social attitudes in the Netherlands had shifted. The change in cultural attitudes was typified by politician Pim Fonteyn's prominent anti-

42 Nicoline Koek interview with the author, 27 June 2011, and 'Flowers for IJburg', Het Blauwe Huis, viewed 7 January 2010, http://www.blauwehuis.org/blauwehuisv2/?project_id=16 Marianne Maasland and Toine Heljmens stated the flower seller attracted people to the neighbourhood, in Paul O'Neill interviews Marianne Maasland 'Locating the Producers, Case Study One-The Blue House', 12 April 2008, p. 4, unpublished, and 'Letter from Toine Heljmens, 2006' in J. van Heeswijk, 2007, Jeanne van Heeswijk, Systems The Green Box Kunst Edition, Berlin, p. 393.

43 According to Igor Roovers interviewed by Paul O'Neill 'Locating the Producers' 1 December 2007, p. 7, unpublished. Nicoline Koek's flower shop 'bloem \& zee' continues today, as does the well-used children's library.

44 Proeflokaal operated in association with Stichting Voorportall, Stichting Dienstveriening, Zorg IJburg and a catering service, to offset more than 12 months wait for the community service restaurant. See Van Heeswijk, Systems, p. 395.

45 Pluralism and participation were promoted as Dutch values by the government, along cultural, geographical and class lines during the 1970s, and subsequently in a liberal approach to drugs, gay marriage and euthanasia. 
immigration platform prior to his assassination in 2002. ${ }^{46}$ Newspaper reports of IJburg residents' complaints against Moroccan neighbours followed the racial and religious (Islamic) discrimination evident in the shooting of Theo van Gogh by Mohammed Bouyeri in November 2004. ${ }^{47}$ Such tensions and lack of tolerance have global echoes particularly after 9/11.

Activist member Jo van der Speck invited undocumented immigrant Cheikh 'Papa' Sakho to stay in The Blue House. Sakho sought asylum, having evaded authorities after surviving the fire in the Schiphol migrant detention centre in 2005. ${ }^{48}$ At The Blue House, Speck and Sakho organised Migrant to Migrant (M2M) radio, a weekly internet program discussing immigration and related issues broadcast on Friday nights. ${ }^{49}$ The M2M broadcast nights included an open invitation to dinner and participation in the evening.

The Frida Project was also conducted by van Heeswijk during 2008 and 2009. Several women, all going under the pseudonym 'Frida', were employed as resident hosts of The Blue House. Assuming responsibility for welcoming guests as part of offering hospitality, including cooking for the M2M project, was not always an easy task for the women. ${ }^{50}$ Some of the women's experiences were also documented by other members. ${ }^{51}$ The reversal of the normative position of illegal workers made visible the position of undocumented workers in the Dutch economy and the contentious and often fraught nature of hospitality at The Blue House, and in the Netherlands more generally.

\section{Researching the Unplanned}

As a social experiment, The Blue House maintained a non-hierarchical organisational structure with a fluid membership supported and led by Jeanne van Heeswijk, and offers a case of 'autonomous' social art with unplanned

\footnotetext{
46 Some campaigners associated immigration with the government's sizable pension liability (with many migrants drawing benefits); in 2006, 7.5 million Dutch workers were supporting one million Dutch on disability pensions, see Tim Colebatch, 'Should going Dutch be the Australian way?', The Age, 23 March 2004, viewed 2 August 2011, http://www.theage.com.au/articles/2004/03/22/1079939577920.html?from=storyrhs 47 Several members of The Blue House recalled a newspaper headline in which a private homeowner protested that he did not want to see Moroccans living in the same street. Van Heeswijk interview with the author, 17 June 2011.

48 At The Blue House Sakho was a guest of the European Cultural Foundation (ECF), which placed him beyond local authorities, according to van Heeswijk interview with the author, 17 June 2011. The ECF participation was part of ALMOSTREAL, an ECF project organised by Igor Dobricic, the arts programme officer of the ECF, in exchange for bringing funding to The Blue House.

$49 \mathrm{M} 2 \mathrm{M}$ radio is at http://M2M.streamtime.org. M2M also offered a meal to visitors on broadcast evenings. 50 Several women found the role too difficult to undertake for long according to van Heeswijk, in Van Heeswijk interview with the author, 17 June 2011.

51 Research for artist Sonia Boyce comprised documentation of her discussions with the longest serving Frida. Sonia Boyce interview with the author, 12 May 2010.
} 
outcomes. Generating dynamic, creative processes of inquiry, social art research at The Blue House falls within Andreas Mueller's description of Participatory Action Research - 'a method that approaches a given situation through research activities, involving participants and existing local social networks' - without aiming at preconceived results. ${ }^{52}$ The conceptual inquiry of The Blue House was differentiated from the 'social service' provision of new genre public art, direct political activism or critical aesthetics based in ethics or art interpreted in terms of political models. ${ }^{53}$ The Blue House employed fields of interaction to generate relations, idiosyncratic critical perspectives and dialogues on urbanism. The selection of projects conducted under the mantle of The Blue House evidences the potential for intersubjective experiences to arise between members and residents through creative processes questioning how to relate to others, and to understand concerns that cross public and private boundaries.

Although outcomes exceeded expectations on the whole, not all projects fulfilled the ambitions of individual members and residents. Some members were disappointed at their inability to generate dialogue and participation, and others disheartened that residents were not able to sustain projects. ${ }^{54}$ Original IJburg residents were critical of the exclusivity of The Blue House, and would have preferred priority be given to the house as a social space, in contrast to the increasing level of general public interest that the project generated over time. ${ }^{55}$ The differing opinions between members and residents, as evident in the Pump Up the Blue, Chill-ROOM and Frida projects, highlighted divergent understandings of notions of public and private space, and the accommodation of differing attitudes and responsibilities toward others. Residents acknowledged that The Blue House contributed to generating a discursive community, and informed the creation of IJburg's early history. ${ }^{56}$

52 Mueller, A. 2009, 'Spatial Practices, Dutch Artistic Research Event \# 3', Mahkuzine Journal of Artistic Research, Utrecht Graduate School of Visual Art and Design, vol. 6, p. 7, viewed 14 February 2011, http:// www.mahku.nl/research/mahkuzine6.html

53 Grant Kester criticises social art that aims to offer social good: 'This puts the artist in the problematic position of being held responsible for rectifying the disempowered status of the disadvantaged instead of insisting on the need for the systematic causes of poverty and other social issues to be alleviated, placing the community artist in the role of a 'social service provider,' in Kester, Conversation Pieces, p. 138. Also see Bishop, C. 2006, 'The Social Turn: Collaboration and Its Discontents', Artforum, vol. 44, no. 6, pp. 178-84. The Blue House was not a form of 'insurgent cosmopolitanism', that writers such as Boaventure de Sousa Santos propose is capable of contradicting the determinism of economic globalisation.

54 Silvia Russel's hopes for continuation of the workshops she conducted for a group of mothers who wanted social and creative outlets proved unrealistic. Paul O'Neill interview with Silvia Russel, 'Locating the Producers', 12 April 2008, p. 5, unpublished.

55 Maarthe van Eerdt interview with the author, 15 June 2011, and Van Heeswijk interview with the author, 17 June 2011.

56 Maarthe van Eerdt interview with the author, 15 June 2011, and Paul O'Neill interview with Marius Knulst, 'Locating the Producers' 11 April 2008. The house received larger numbers of general visitors in its later years, according to van Heeswijk, in Van Heeswijk interview with the author, 17 June 2011. 
Art historian Hal Foster identified the risk of artists acting as quasianthropologists when responding subjectively to communities and cultures. ${ }^{57}$ Foster's criticism was based in a textual interpretation of (non-social) artworks in the mid-1990s, but remains relevant to the unprogrammatic practices of social artists. However, at The Blue House residents were not treated as a generalised other. Members interacted with neighbours in intuitive, if heuristic ways in the creation of interventions into the 'unplanned'. In addition, the majority of The Blue House members were Dutch or European and were familiar with the cultural nuances of living in Amsterdam. Members also had the assistance of the house manager, and the time to engage with the situation without being pressured to produce outcomes. The Block 35 Housing Association was also a control mechanism, with the residents having power to stop The Blue House projects. ${ }^{58}$ Finally, the membership structure, comprising an interdisciplinary mix of outsiders and residents, provided a supportive and critical framework. Aware of the miscellany of sensibilities and beliefs existing in the proximity of Block 35, members sought common points of reference with individual neighbours to activate research projects.

Consequently, I argue, creative and social research and cultural production at The Blue House were brought about through a 'creative milieu' generated under the leadership of van Heeswijk. ${ }^{59}$ There is no evidence of a communal feeling developing at Block 35, or of more than periodic association between members. Members physically came together at a few events, such as the closing symposium, otherwise only communicating over significant issues. In being responsive to site and individuals at IJburg, I find the uninvited guests of The Blue House membership accorded with Patricia Reed's concept of being simultaneously host and 'un-host' ${ }^{60}$ Reed's concept suggests a consequent blurring of control and agency. The Blue House provided capacity for agency at an individual level. Members and residents at IJburg could find themselves as participants or observers at different moments over the five years of the project. Both residents and members could be seen to participate within their individual

57 Foster, H. 1996, 'The Artist as Ethnographer', The Return of the Real, The Avant-Garde at the Turn of the Century, Cambridge, Mass, MIT Press, pp. 171-204.

58 Proposals for Pump Up the Blue and the Chill-Room were disputed by residents through the Association, activated only after convincing the Association of their public validity and taking responsibility for any potential private impact. Van Heeswijk interview with the author, 17 June 2011.

59 The idea of milieu, as a set or sets of complex networks 'of mainly informal social relationships within a specific internal "representation" and a sense of belonging, which enhance the local innovative capability through synergetic and collective learning processes' is seen as a common point of reference essential for understanding and thus for communication and knowledge transfer (especially tacit knowledge transfer), in Heßler, M. and Zimmermann, C. (eds) 2008, Creative Urban Milieus, Historical Perspectives on Culture, Economy, and the City, Frankfurt/New York, Campus Verlag, pp. 385-6.

60 'Throughout the process of un-hosting a degree of control (not all) is dispersed and it is precisely that dispersion of "control" that blurs conventional notions of authorship' according to Patricia Reed, in D. Goldenberg and P. Reed, 2008, 'What is a Participatory Practice?', Fillip, viewed 29 June 2010, http://fillip. ca/content/what-is-a-participatory-practice 
creative milieu, one that was based in the contingent investigation of how to be a good neighbour or guest. At best The Blue House generated individual appreciation of the potential of social processes for agency or intersubjective awareness within a larger milieu or personal world. Operating at the level of individuals, I contend social art at The Blue House was differentiated from the concepts of community suggested for social or dialogic art by Grant Kester, or Bourriaud's utopian model of communicative action in relational aesthetics.

In a seeming contradiction, van Heeswijk's success in leading independent social art at The Blue House also offered potential administrative outcomes of the sort she aimed to avoid. Many Blue House projects fulfilled the 'high imagination enabling' and do-it-yourself attitudes advocated for artists in creative cities, and contributed to generating economic and cultural capital. ${ }^{61}$ In organising The Blue House, van Heeswijk epitomised the entrepreneurial abilities appreciated by urban policy and commerce for responsiveness to local and global markets, namely: being autonomous, able to generate income, demonstrating excellent negotiation skills, and acting as an inspiring manager who could mentor others.

In addition, Igor Roovers, Director of Projectburo IJburg, indicated interest in instrumentally applying his learning from The Blue House in more organic neighbourhood development and responsive city planning in the future. ${ }^{62}$ Roovers had remained engaged across the duration of The Blue House after van Heeswijk refused his initial offer to fund the project. Although ultimately disinterested in the project as art, Roovers concluded The Blue House created a civic space, and maintained a similar project operating during Phase II of IJburg construction would likewise benefit the city. ${ }^{63}$

Roovers' response indicated that despite delivering pragmatic outcomes and indicating the intersubjective potential of social art, The Blue House evidenced the risk of social art projects being diverted into value for commercial urban developers or implicated in social policy, in contrast to the ideal political function of Bourriaud's relational aesthetics. The Blue House attracted community interest and improved the quality of life at no cost to the Projectburo. By default, The Blue House also delivered the Dutch national cultural policy objective of fostering the participation of young people and immigrants in cultural expression on IJburg. ${ }^{64}$

61 Relevant Blue House projects in this regard included a website to connect local business people, and Koek's Flowers for IJburg which generated economic income or replaced market exchanges.

62 Roovers interview with the author, 21 May 2010.

63 Igor Roovers interviewed by Paul O'Neill 'Locating the Producers', 1 December 2007, p. 7, unpublished. 64 Ministry of Education, Culture and Science, Cultural Policy in the Netherlands, 12. The Blue House was also appropriated in real estate sales promotions. 


\section{Conclusion}

Fostering creativity with the potential to generate social and cultural worlds, The Blue House encouraged interpersonal or cosmopolitan imagination, and communicative interaction and networks connecting members and residents at IJburg. The project also mobilised a dispersed international and travelling membership, with linkages across the milieu resembling the concept of Nikos Papastergiadis' 'spatial aesthetics' ${ }^{65}$ Dispersed members employed digital networks to share information and promote relations, document research and maintain contacts. In the thinking of van Heeswijk, members transferring The Blue House research to other sites and times became 'Blue Points'. Two 'Blue Points' have subsequently been established in Amsterdam, one artist basing his social practice in a city shopping mall, and another operating from a domestic space. Members have also co-created projects addressing local urban concerns in Hong Kong and Latin America. ${ }^{66}$

In their dynamic creative connections, the 'Blue Points' resemble the 'nodes' that Arjun Appadurai refers to as connecting points within 'a complex transnational construction of imaginary landscapes' ${ }^{67}$ The Blue House members entered into the transnational hegemony of global neoliberalism through local actions. ${ }^{68}$ In requiring individuals to think about how to make connections to others and their singular worlds in uneven economic, social and cultural conditions, The Blue House may be useful in rethinking global communities in ways similarly appreciated by Nancy Fraser. Fraser proposes the ongoing critical relevance of a transnational public sphere based in a critical problematising of normative models for democractic and emanicipatory politics. ${ }^{69}$ Overall, the individual actions and communications of The Blue House generated potential political agency and creative social resources in responding locally to the world-making of global society. The dispersed and mobile members continue the potential for the ongoing galvanising of individual learning and reach of relations from IJburg. In this sense, The Blue House project offers an example of how artists 'reshape the human capacity to make worlds on small, local scales' while bolstering hope that contemporary art is 'becoming art of the world'.$^{70}$

\footnotetext{
65 Papastergidis, N. 2006, Spatial Aesthetics. Art, Place and the Everyday, London, Rivers Oram Press.

66 Organised with Hong Kong member and curator Howard Chan, and the Argentinian collective M7red.

67 Appadurai, A. 1996, 'Disjunctures and Differences in the Global Cultural Economy', in A. Appadurai, Modernity at Large: Cultural Dimensions of Globalization, Minneapolis, University of Minnesota Press, p. 33. 68 Processes of economic globalisation, defined as the transnational spread or hegemony of neoliberalism at the expense of state boundaries and social interests, according to Santos, 'Globalisations', pp. 393-4.

69 Fraser proposes a transnational public sphere requires new forms of political accountability to publics embracing greater inclusiveness or a parity of participation. See Nancy Fraser, 2007, 'Transnationalizing the Public Sphere: On the Legitimacy and Efficiency of Public Opinion in a Post-Westphalian World', Theory, Culture \& Society, vol. 24, no. 4, pp. 7-30.

70 I extend thanks to the anonymous reviewers of this article for their comments on the power of the social in world making in art.
} 